\title{
Article \\ Light-Intercepting Characteristics and Growth of Tomatoes Cultivated in a Greenhouse Using a Movable Bench System
}

\author{
Yuta Ohashi ${ }^{1,2}{ }^{\text {, Misato Murai }}{ }^{1}$, Yasuhiro Ishigami ${ }^{1,3}(\mathbb{D})$ and Eiji Goto ${ }^{1,4, *(D)}$ \\ 1 Graduate School of Horticulture, Chiba University, Matsudo 648, Chiba 271-8510, Japan; \\ yuta.ohashi@gmail.com (Y.O.); misatomurai0522@gmail.com (M.M.); ishigami@takasaki-u.ac.jp (Y.I.) \\ 2 Institute for Rural Engineering, NARO, Tsukuba 305-8609, Japan \\ 3 Faculty of Agriculture, Takasaki University of Health and Welfare, Takasaki 370-0033, Japan \\ 4 Plant Molecular Research Center, Chiba University, Chiba 260-0856, Japan \\ * Correspondence: goto@faculty.chiba-u.jp
}

Citation: Ohashi, Y.; Murai, M.; Ishigami, Y.; Goto, E. Light-Intercepting Characteristics and Growth of Tomatoes Cultivated in a Greenhouse Using a Movable Bench System. Horticulturae 2022, 8, 60. https://doi.org/10.3390/ horticulturae 8010060

Academic Editor: Zhilong Bie

Received: 27 November 2021

Accepted: 2 January 2022

Published: 9 January 2022

Publisher's Note: MDPI stays neutral with regard to jurisdictional claims in published maps and institutional affiliations.

Copyright: (c) 2022 by the authors. Licensee MDPI, Basel, Switzerland. This article is an open access article distributed under the terms and conditions of the Creative Commons Attribution (CC BY) license (https:/ / creativecommons.org/licenses/by/ $4.0 /)$.

\begin{abstract}
The objective of this study was to investigate the growth and light-intercepting characteristics of tomatoes when movable benches are used in their cultivation. We cultivated tomatoes in a greenhouse $\left(168 \mathrm{~m}^{2}\right.$ ) during summer (9 July-9 September 2018) under different furrow distances $(\mathrm{F} 1.0=1.0 \mathrm{~m}$ and F1.6 $=1.6 \mathrm{~m})$ and movable benches $(\mathrm{M}$ indicates that the furrow distance $=0.4-0.8 \mathrm{~m})$. Compared to the other treatments, when the movable bench was used to the change furrow distance depending on the plant growth stage ( $\mathrm{M}$ treatment), the percentage of canopy light interception increased to $\sim 90 \%$ at the early stage of plant growth ( 20 days after transplanting). The percentage of canopy light interception for different treatments increased in the order of M > F1.0 > F1.6, and it increased towards the end of cultivation. In addition, the yield per unit area exhibited the same trend. Therefore, the solar radiation inside a greenhouse can be efficiently intercepted by plants when movable benches are used. This indicated that it was possible to increase plant yield per unit area using movable benches in plant cultivation.
\end{abstract}

Keywords: leaf area index; light environment; light extinction coefficient; plant height; R/FR ratio; shade avoidance; Solanum lycopersicum

\section{Introduction}

The tomato is top-ranked among vegetables grown worldwide [1]. In 2019, the total cultivation area and production of tomatoes globally were approximately 5.0 million ha and 181 million tons, respectively [2]. Since the demand for tomatoes is predicted to increase because of population growth in the future, technology for efficient tomato production needs to be developed. Greenhouse cultivation is a flexible solution for the sustainable year-round cultivation of tomatoes regardless of climatic, land, and resource limitations [3].

In a modern greenhouse, automated movable benches can facilitate cultivation management and increase plant yield. Studies have been conducted on the cultivation of fruit vegetables using movable benches for the efficient use of space inside a greenhouse. Movable benches allow for higher plant densities per unit area because pathways between the vegetables are not needed [4]. To increase strawberry yield, Yoshida et al. (2008) developed a movable bench that allowed for a density of 125,000 plants per ha [5]. Hayashi et al. (2008) reported that when a movable bench was used for strawberry cultivation, the plant density was almost twice that under traditional greenhouse cultivation because the space for access was reduced [6]. Hayashi et al. (2011) showed that when movable benches were used, the marketable yields of strawberry cultivars 'Akihime' and 'Moikko' doubled compared to the conventional yield [7]. Therefore, the use of movable benches in tomato cultivation may increase space utilization efficiency and yield. Movable benches allow cultivators to change the furrow distance depending on the plant growth stage to reduce the use area and provide a suitable leaf area index (LAI). As a result, the light interception per unit area can 
be maximized and the yield per unit area can be increased. Jiang et al. (2017) reported that the total winter yield of tomatoes per unit area was higher when movable benches were used (25-11.1 plants $\mathrm{m}^{-2}$ ) with the single-truss system (STS) compared to that without movable benches at 10 and 14.3 plants $\mathrm{m}^{-2}$ [8]. In STS tomato growing, only the first truss is harvested and the main shoot is cut above the first truss [9]. In general, the use of STS for cultivation requires high plant densities. Therefore, the light environment inside the canopy is important for increasing plant yield under these conditions.

Unlike the cultivation of plants with low heights, such as strawberries, it is difficult to determine the furrow distance when movable benches are used in the cultivation of fruit vegetables with high plant heights, such as tomatoes. This is because their large canopies interfere with each other, reducing the light interception.

Mutual shading affects tomato morphology, growth, and yield. Papadopoulos and Ormrod (1991) observed that the plant height and internode length of tomato increased as the plant spacing decreased from 60 to $23 \mathrm{~cm}$ in both spring and fall [10]. In addition, the relationship between plant density and tomato yield has been reported in previous studies [11-13]. Papadopoulos and Ormrod (1990) reported that when tomatoes were cultivated with different plant spacings $(23,30,38,45,53$, and $60 \mathrm{~cm})$, the yield per plant reduced to a greater extent in the spring than in the fall as the plant spacing decreased [12]. Papadopoulos and Ormrod (1991) described that with a decrease in plant spacing, the fruit set rate more steeply declined in the spring than in the fall [10].

When movable benches are used to change the furrow distance, the light environment inside the canopy changes as well, thereby affecting plant growth. Therefore, the objective of the present study was to investigate the growth and light intercepting characteristics of tomatoes when movable benches are used in their cultivation.

\section{Materials and Methods}

\subsection{Test Plants and Greenhouse Conditions}

Tomatoes (Solanum lycopersicum L.) cv. 'Reika' (SAKATA SEED Co., Ltd., Kanagawa, Japan) were cultivated in the summer (July 9-September 9, 2018) inside a greenhouse $\left(164 \mathrm{~m}^{2}\right.$, width $\times$ length $\times$ average height $\left.=8 \times 18 \times 4 \mathrm{~m}\right)$. The greenhouse was located in Matsudo, Chiba, Japan and had a single ridge gable roof type. A polyolefin film was used as the covering material. Three weeks after sowing, the tomato seedlings were transplanted into rockwool cubes (DELTA6.5G, Rockwool B. V., Roermond, Netherlands) installed on rockwool slabs (2075 A2W, Rockwool B. V., Roermond, Netherlands). The distance between the plants was $22 \mathrm{~cm}$, and the plants were arranged in a zigzag pattern. A one-fold concentration of A recipe (OAT Agrio Co., Ltd., Tokyo, Japan) was used as the nutrient solution, and the plants were irrigated with the solution using an automatic irrigation device (JS110-08D, JOP Co., Ltd., Aichi, Japan).

The cultivation benches were arranged as shown in Figure 1. The furrow distance was set at $1.6 \mathrm{~m}$ (treatment F1.6), 0.4-0.8 m (treatment M), and $1.0 \mathrm{~m}$ (treatment F1.0) from the north side in the greenhouse (Figure 1). Using movable benches, the furrow distance in the $\mathrm{M}$ treatment was changed depending on the growth stage of the plants in order to avoid contact between the plants and leaves of other canopies. We cultivated sixty-four tomato plants for each treatment. Figure 2 illustrates the changes in furrow distance during cultivation. Figure 3 and Table 1 show the environmental conditions of the greenhouse. The air temperature and vapor pressure inside the greenhouse were measured and controlled using an integrated environmental control system (Profarm controller, Denso Co., Ltd., Aichi, Japan). Figure 4 shows the tomato plants under different treatments after transplanting inside the greenhouse. 


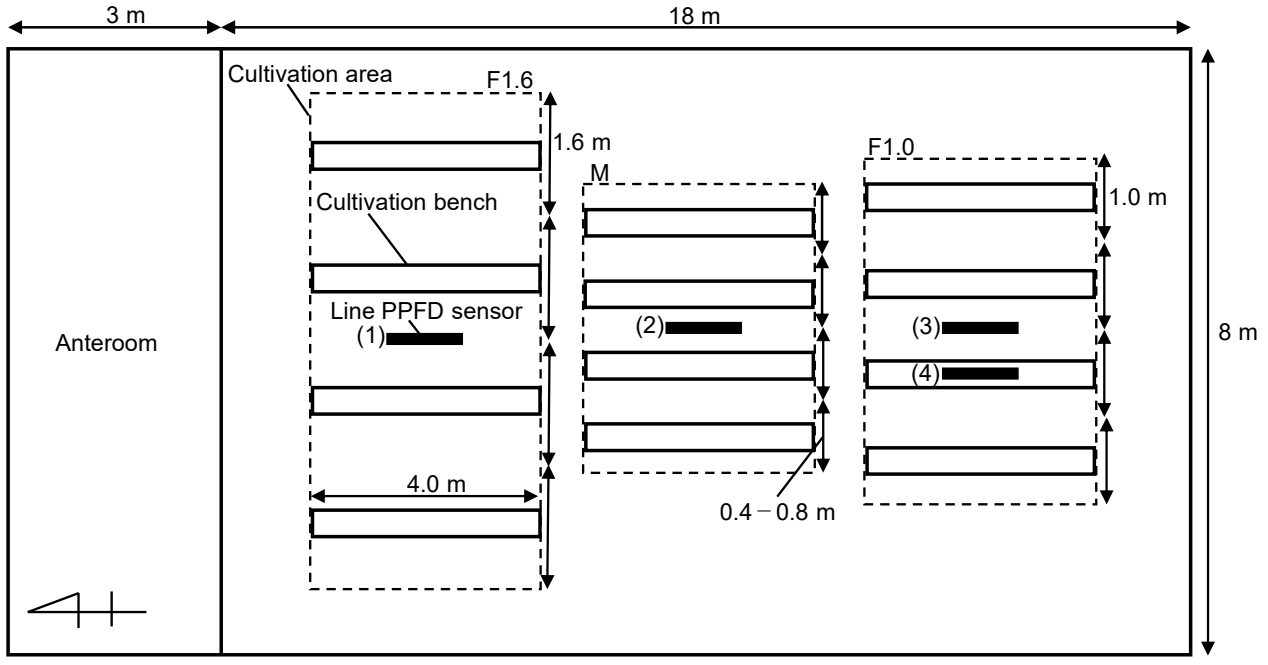

Figure 1. Experiment layout, including the cultivation benches; the black line represents the location of photosynthetic photon flux density (PPFD) sensors in the greenhouse. The plant distance is $22 \mathrm{~cm}$. F1.6 and F1.0 treatments have furrow distances of 1.6 and $1.0 \mathrm{~m}$, respectively; in the $\mathrm{M}$ treatment, furrow distance was changed from 0.4 to $0.8 \mathrm{~m}$ during cultivation using movable benches. The line PPFD sensors 1-3 were used to calculate the percentage of canopy light interception, whereas sensor 4 was used to calculate the light extinction coefficient of the tomato canopy.

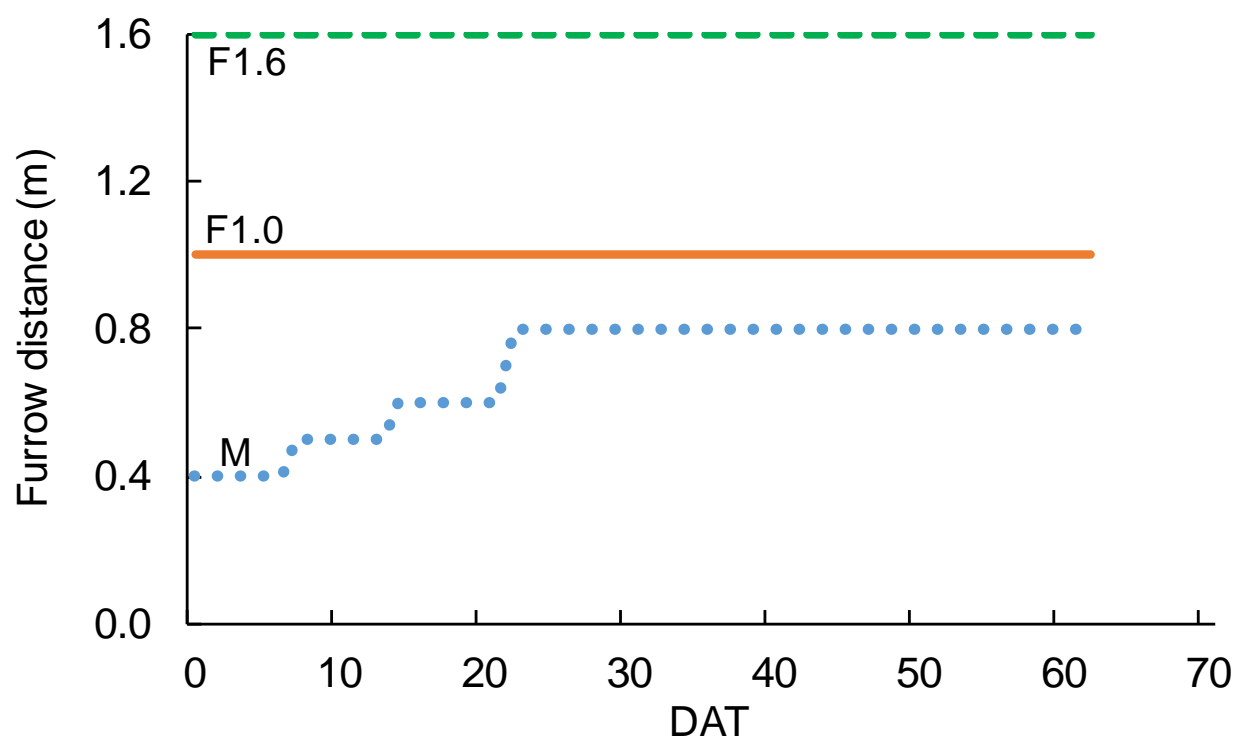

Figure 2. Changes in furrow distances during tomato cultivation. $M$ indicates that the furrow distance was changed from 0.4 to $0.8 \mathrm{~m}$ during cultivation using movable benches; F1.6 and F1.0 are furrow distances of 1.6 and $1.0 \mathrm{~m}$, respectively. Movable benches $(\mathrm{M})$ were used to change the furrow distance during the cultivation. DAT, days after transplanting. 

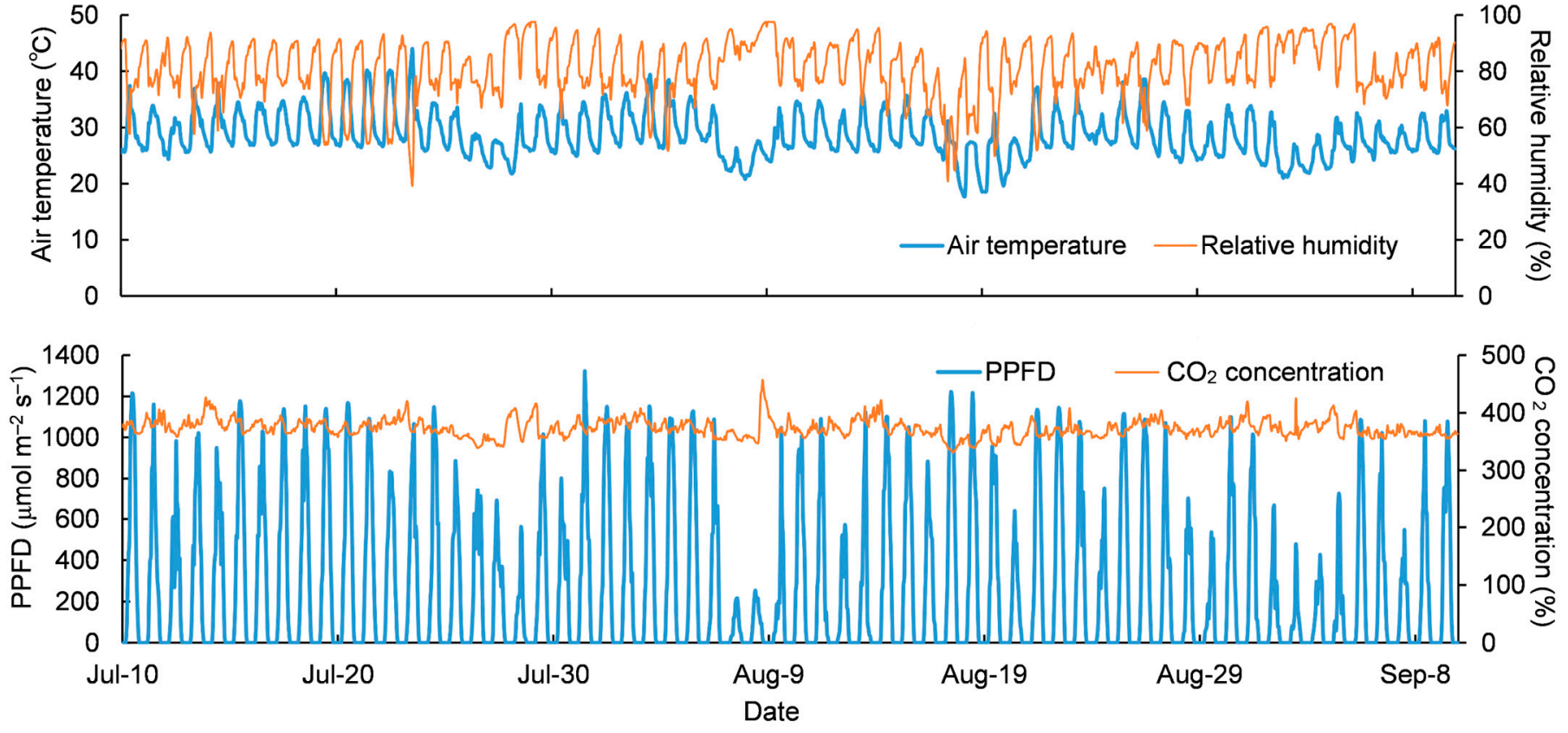

Figure 3. Time courses of hourly air temperature, relative humidity, photosynthetic photon flux density (PPFD), and $\mathrm{CO}_{2}$ concentration in the greenhouse during the experiment.

Table 1. Environmental conditions in the greenhouse during the experiment.

\begin{tabular}{|c|c|c|c|c|c|c|}
\hline $\begin{array}{l}\text { Cultivation } \\
\text { Period }\end{array}$ & Time & $\begin{array}{l}\text { Integrated PPFD } \\
\left(\mathrm{mol} \mathrm{m}^{-2} \mathrm{~d}^{-1}\right)\end{array}$ & $\begin{array}{c}\text { Air } \\
\text { Temperature } \\
\left({ }^{\circ} \mathrm{C}\right)\end{array}$ & $\begin{array}{c}\mathrm{CO}_{2} \\
\text { Concentration } \\
\left(\mu \mathrm{mol} \mathrm{mol}{ }^{-1}\right)\end{array}$ & $\begin{array}{c}\text { Relative } \\
\text { Humidity (\%) }\end{array}$ & $\begin{array}{c}\text { Vapor Pressure } \\
\text { Deficit (kPa) }\end{array}$ \\
\hline 10 July-9 & 5:00-19:00 & 23.1 & $30.6 \pm 3.9$ & $370.5 \pm 15.4$ & $77.0 \pm 10.3$ & $0.78 \pm 0.48$ \\
\hline September 2018 & 19:00-5:00 & 0.0 & $26.1 \pm 2.3$ & $376.7 \pm 14.6$ & $86.4 \pm 6.6$ & $0.34 \pm 0.18$ \\
\hline
\end{tabular}

The values of air temperature, $\mathrm{CO}_{2}$ concentration, relative humidity, and vapor pressure deficit are expressed as mean \pm standard deviation. PPFD, photosynthetic photon flux density.

F1.6

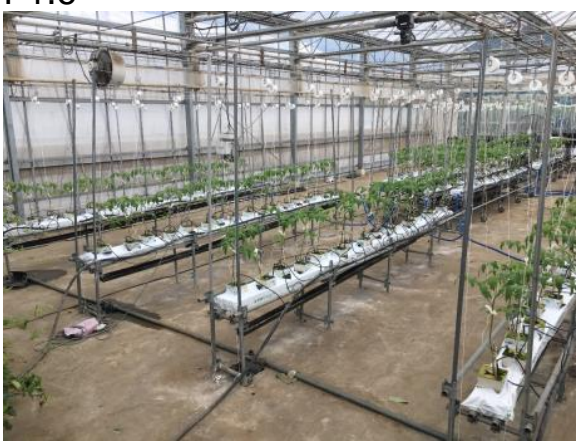

M

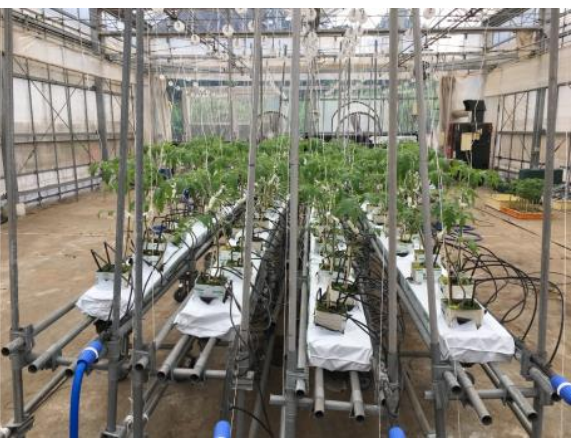

$\mathrm{F} 1.0$

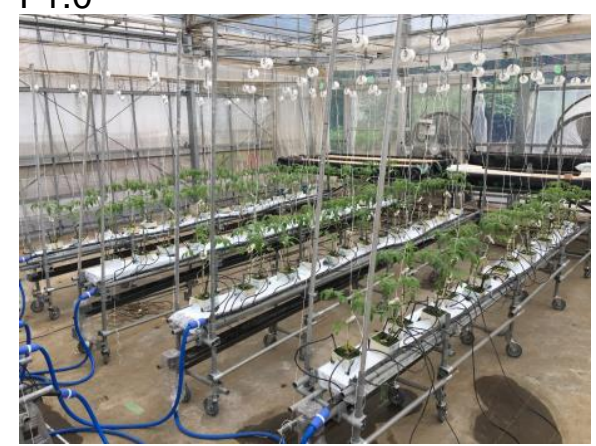

Figure 4. The tomato canopies under different treatments in the greenhouse on 12 July 2018. F1.6 and F1.0 indicate furrow distances of 1.6 and $1.0 \mathrm{~m}$, respectively; $\mathrm{M}$ indicates that the furrow distance was changed from 0.4 to $0.8 \mathrm{~m}$ during cultivation using movable benches.

\subsection{Light Interception Characteristics}

Line photosynthetic photon flux density (PPFD) sensors (SQ-311, Apogee Instruments Inc., Logan, UT, USA) were installed inside the tomato canopies in the three treatments (Figure 1), and PPFD was measured every minute during the cultivation period. The percentage of canopy light interception was calculated using the following formula: 
Percentage of canopy light interception $(\%)=\left(1-\frac{\text { PPFD at the bottom of the canopy }}{\text { PPFD at the top of the canopy }}\right) \times 100$

When the percentage of canopy light interception was higher, the solar radiation inside the greenhouse could be efficiently intercepted by the plants. Higashide (2018) reported that an increase in the LAI increases the percentage of canopy light interception [14].

When movable benches are used to control plant density, it is important to assess the LAI during cultivation to avoid excessively high LAIs. Blanco and Folegatti (2003) estimated the leaf area of tomatoes and cucumbers using leaf length and width [15]. However, this method requires a long time and is not suitable for commercial cultivation. Thus, in this study, the light extinction coefficient $(K)$ was used to estimate the LAI [16]. Therefore, we investigated the relationship between the furrow distance and $K$.

Equation (2) was converted to Equation (3) to calculate $K[17,18]$ :

$$
I=I_{0} e^{-K F}
$$

where $I$ indicates the PPFD at the bottom of the canopy, $I_{0}$ indicates the PPFD over the canopy, $K$ is the light extinction coefficient, and $\mathrm{F}$ is the LAI.

$$
K=\frac{1}{F} \times \ln \frac{I_{0}}{I}
$$

To obtain $K$ under various furrow distance conditions, line PPFD sensors were installed at the bottom and over the canopy in the F1.0 treatment. The PPFD values at the bottom and over the canopy were measured every minute on sunny days during the period of 36-38 days after transplanting (DAT) and on 48 DAT. The above-described measurements were conducted for 30 min each at furrow distances of 40,60, 80,100,120,140, and $160 \mathrm{~cm}$. The furrow distances were changed using a movable bench. The average PPFD values at the bottom and over the canopy were used to calculate K values. We used Equation (4) to estimate the leaf area used to calculate the LAI.

$$
\text { Leaf area }\left(\mathrm{cm}^{2}\right)=\text { leaf length }(\mathrm{cm}) \times \text { leaf width }(\mathrm{cm}) \times 0.25
$$

Using linear regression, Flénet et al. (1996) observed a positive correlation between LAI and $K$ in the canopies of corn, sorghum, soybean, and sunflower [19]. In the present study, an observation of a linear correlation between the furrow distance and $K$ in the tomato canopy under different furrow distances was useful for discussing the light conditions and LAI in the tomato canopy.

\subsection{Plant Growth and Yield}

The leaf area and dry weight of each plant part (leaf, stem, and fruit) were measured at 30 and 62 DAT. Leaf area was measured using an area meter (LI-3100, LI-COR Inc., Lincoln, NE, USA). The dry matter ratio was calculated using the leaf dry weight and leaf fresh weight. The dry matter distribution was calculated using the dry weight data for each plant part. Specific leaf weights were calculated using the leaf area and leaf dry weight data. Growth data were statistically evaluated by one-way analysis of variance (ANOVA) using SPSS Statistics 24.0 (IBM Inc., Armonk, NY, USA). To investigate the significant differences among treatments, the means of measurement parameters were compared using the Tukey-Kramer test at a significance level of $p<0.05$.

The mature fruits of the first truss were harvested at 54 DAT, and their fresh weights were measured.

Leaf length, leaf width, and plant height were non-destructively measured once a week. The change in the LAI of each treatment was recorded using the estimated leaf area calculated using Equation (4). 


\subsection{Fruit Temperature}

Tomato plants were cultivated at different furrow distances. Therefore, it was considered that the furrow distance affected the light environment and fruit temperature inside the canopy. The fruit temperature was found to affect the translocation of photosynthates in tomatoes [20]. The central temperature of the fruit (first truss) in the F1.6 and M treatments was measured from 7 to 9 September 2018, using a copper-constantan thermocouple. We inserted a copper-constantan thermocouple into three F1.6 and M tomato fruits. The fruit temperature was recorded every minute using a data logger (GL220, GRAPHTEC Inc., Kanagawa, Japan).

\section{Results and Discussion}

\subsection{Light Interception Characteristics}

Figure 5 shows the percentage of canopy light interception in the three treatments. The percentage of canopy light interception descended in the order of M > F1.0 > F1.6, and it increased towards the end of cultivation. Moreover, the period until the saturation of canopy light interception percentage ( 90\%) was shorter in the M treatment (at 20 DAT) than that in the other treatments. The maximum percentage of canopy light interception in the F1.6 treatment was $~ 80 \%$. Kaneko et al. (2015) indicated that it was important to increase the percentage of canopy light interception in tomatoes to increase the plant yield per unit area [21]. Papadopoulos and Pararajasingham (1997) reported that it was possible to obtain a higher yield of tomatoes under narrow plant spacing than under wider plant spacing because the former increased the percentage of canopy light interception [13]. Therefore, we considered that the movable bench was a good solution to increase the percentage of canopy light interception and yield. Ota et al. (2016) developed an automatic spacingcontrolled movable bench system, which was controlled by motors and a programmable logic controller, for high-density tomato cultivation [22]. If such a system can utilize canopy light interception information, it can help develop cultivation methods that reduce labor and produce high yields.

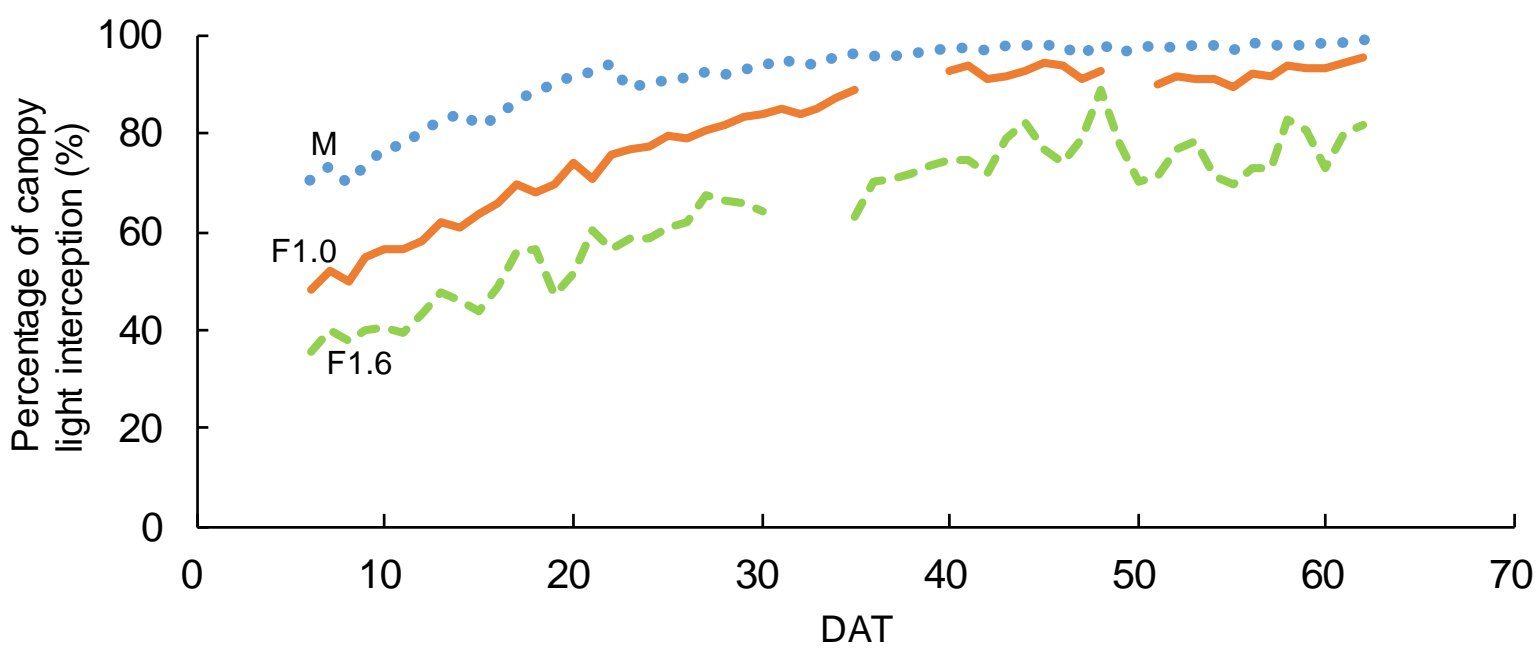

Figure 5. Daily changes in the percentage of canopy light interception in the three treatments. F1.6 indicates a furrow distance of $1.6 \mathrm{~m}, \mathrm{~F} 1.0$ indicates a furrow distance of $1.0 \mathrm{~m}$, and M indicates that the furrow distance was changed from 0.4 to $0.8 \mathrm{~m}$ during cultivation using movable benches. DAT, days after transplanting. In F1.6 and F1.0, data were missing due to PPFD sensor troubles.

Figure 6 shows the relationship between the furrow distance and $K$, which presented a linear correlation $\left(\mathrm{R}^{2}=0.82\right)$. Therefore, $K$ can be estimated using the relationship between furrow distance and $K$. Leaf length and width were measured once a week to estimate the LAI. Since the measurement takes a long time in a commercial greenhouse, this relation will be useful for estimating the LAI and suitable furrow distances in the future. 


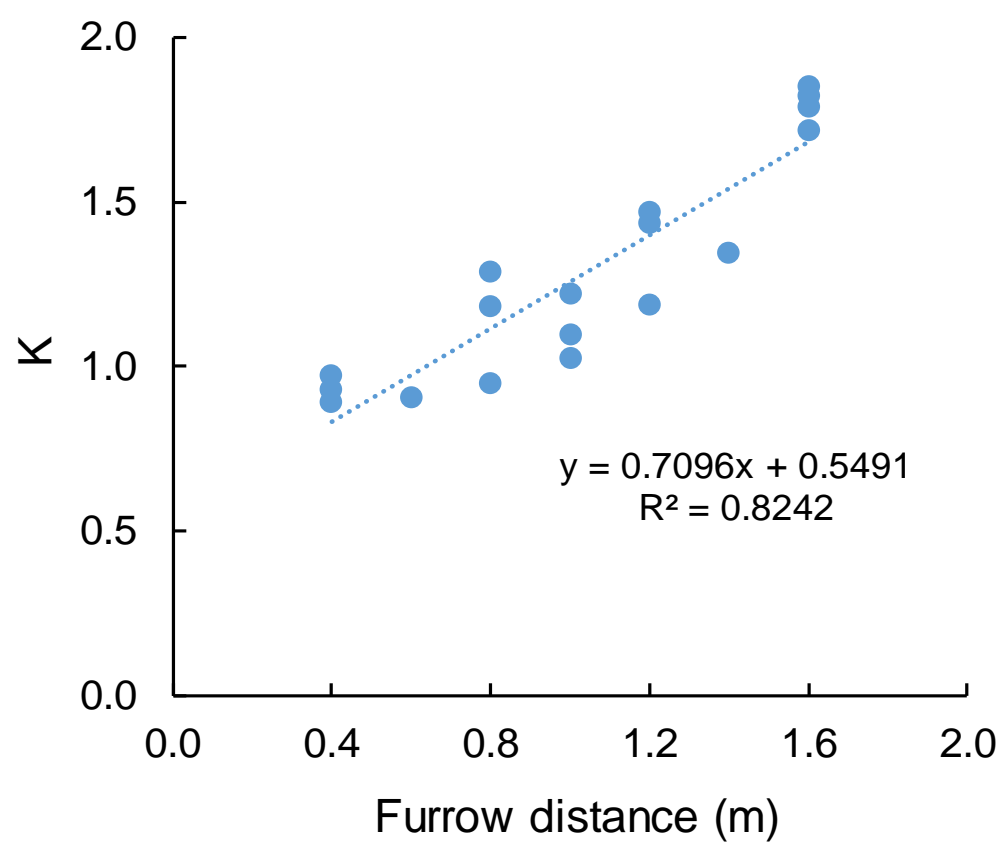

Figure 6. Relationship between the furrow distance and the light extinction coefficient $(K)$. Photosynthetic photon flux densities inside and over the canopy were measured in 2018 at 36-38 days after transplanting (DAT) and on 48 DAT.

\subsection{Plant Growth and Yield}

Table 2 shows the results of growth measurements. At 30 and 62 DAT, the leaf area of plants in the $\mathrm{M}$ treatment was significantly larger than that of plants in the F1.6 and F1.0 treatments. At 30 and 62 DAT, the specific leaf weight of plants in the F1.6 treatment was significantly larger than that of plants in the M and F1.0 treatments. At $30 \mathrm{DAT}$, the aboveground dry weight of plants in the $M$ treatment was higher than that of plants in the F1.6 and F1.0 treatments. However, at 62 DAT, the dry weight of plants in the F1.6 treatment was higher than those of plants in the M and F1.0 treatments. At 30 and 62 DAT, the dry matter ratio of plants in the F1.6 treatment tended to be higher than those of plants in the M and F1.0 treatments. The leaf area of plants in the M treatment was larger than those of plants in the other treatments (Table 2) because of the shade-avoidance reaction probably induced by a low red/far red (R/FR) ratio. In general, the far-red radiation transmittance $(700-800 \mathrm{~nm})$ of the leaves was higher than their photosynthetically active radiation transmittance (400-700 nm). Papadopoulos and Ormrod (1988) reported that the R/FR ratio inside the tomato canopy decreased with decreases in plant spacing [23]. Chitwood et al. (2015) indicated that the shade-avoidance reaction caused an increase in the leaf area of tomatoes because of increased palisade and pavement cell sizes [24]. Therefore, the R/FR ratio inside the canopy of plants in the M treatment was probably lower than those of plants in the other treatments because of the narrower furrow distances (Figure 2) and larger LAI (Figure 7) in the M treatment, which was the result of the expanded leaf area. Figure 7 shows the changes in the LAI during the cultivation period. From highest to lowest, the LAI under different treatments was M > F1.0 > F1.6. The maximum LAI values of plants in the M, F1.0, and F1.6 treatments were 3.8, 2.3, and 1.5, respectively. We found that it was possible to increase the LAI using movable benches throughout cultivation. 
Table 2. Effects of furrow distance on the growth of tomatoes.

\begin{tabular}{|c|c|c|c|c|c|}
\hline DAT & Treatment & $\begin{array}{l}\text { Aboveground Dry } \\
\text { Weight (g plant }^{-1} \text { ) }\end{array}$ & $\begin{array}{c}\text { Dry Matter } \\
\text { Ratio (\%) }\end{array}$ & $\begin{array}{c}\text { Leaf Area } \\
\left(\mathrm{cm}^{2} \text { plant }^{-1}\right)\end{array}$ & $\begin{array}{c}\text { Specific Leaf } \\
\text { Weight }\left(\mathrm{g} \mathrm{m}^{-2}\right)\end{array}$ \\
\hline \multirow{3}{*}{30} & F1.6 & $37.4 \mathrm{a}$ & 12.5 & $2819.4 \mathrm{~b}$ & $74.6 \mathrm{a}$ \\
\hline & $\mathrm{M}$ & $43.7 \mathrm{a}$ & 10.6 & $4351.8 \mathrm{a}$ & $62.2 \mathrm{~b}$ \\
\hline & F1.0 & $36.1 \mathrm{a}$ & 11.2 & $3330.8 \mathrm{~b}$ & $64.9 \mathrm{~b}$ \\
\hline \multirow{3}{*}{62} & F1.6 & $134.5 \mathrm{a}$ & 11.0 & $5341.4 \mathrm{~b}$ & $105.3 \mathrm{a}$ \\
\hline & M & $119.1 \mathrm{a}$ & 10.0 & $10255.1 \mathrm{a}$ & $62.2 \mathrm{~b}$ \\
\hline & F1.0 & $106.3 \mathrm{a}$ & 10.4 & $6784.6 \mathrm{~b}$ & $78.5 \mathrm{~b}$ \\
\hline
\end{tabular}

Different lowercase letters indicate significant differences among the measurements $(n=3)$ at $p<0.05$ according to Tukey-Kramer's test. F1.6 and F1.0 indicate furrow distances of 1.6 and $1.0 \mathrm{~m}$, respectively; M indicates that the furrow distance was changed from 0.4 to $0.8 \mathrm{~m}$ during cultivation using movable benches. DAT, days after transplanting. Growth measurements were conducted on 8 August and 9 September 2018.

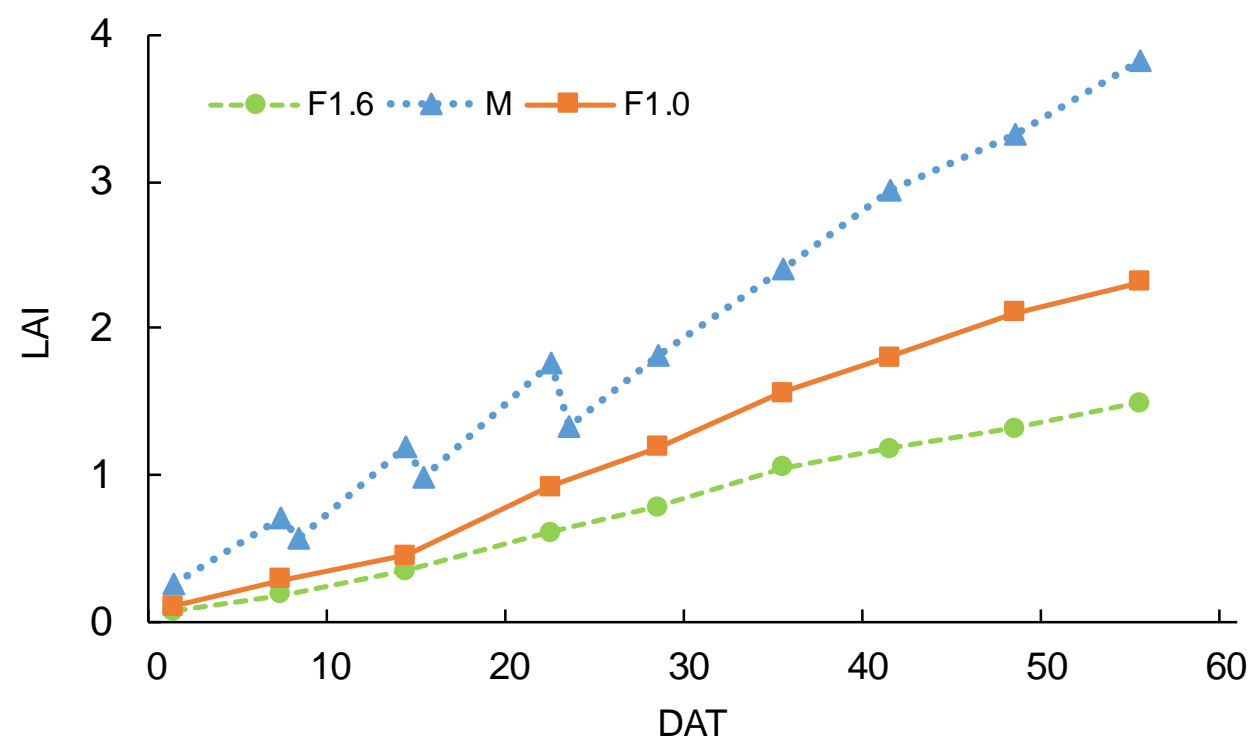

Figure 7. Changes in the leaf area index (LAI) at different furrow distances $(n=3)$. F1.6 and F1.0 indicate furrow distances of 1.6 and $1.0 \mathrm{~m}$, respectively; $\mathrm{M}$ indicates that the furrow distance was changed from 0.4 to $0.8 \mathrm{~m}$ during cultivation using a movable bench. DAT, days after transplanting. The leaf area used to calculate the LAI was measured non-destructively.

Figure 8 shows the relationship between the LAI and the percentage of canopy light interception using the data in Figures 5 and 7 . The tendency of relationships differed among treatments. The results indicated that the light interception characteristics of canopies changed depending on the furrow distance. If cultivation management is conducted to maintain the LAI, where the percentage of canopy light interception is high $(\sim 90 \%)$ considering the furrow distances, growth and yield will be expected to increase.

Figure 9 shows the changes in plant height during cultivation. Plant heights tended to be higher among the plants in the $\mathrm{M}$ treatment than in the plants under other treatments. In the $\mathrm{M}$ treatment, the shade-avoidance reaction induced by the low $\mathrm{R} / \mathrm{FR}$ ratio probably caused stem elongation and leaf expansion. Furrow distance affected plant morphological traits, including plant leaf area and plant height. 

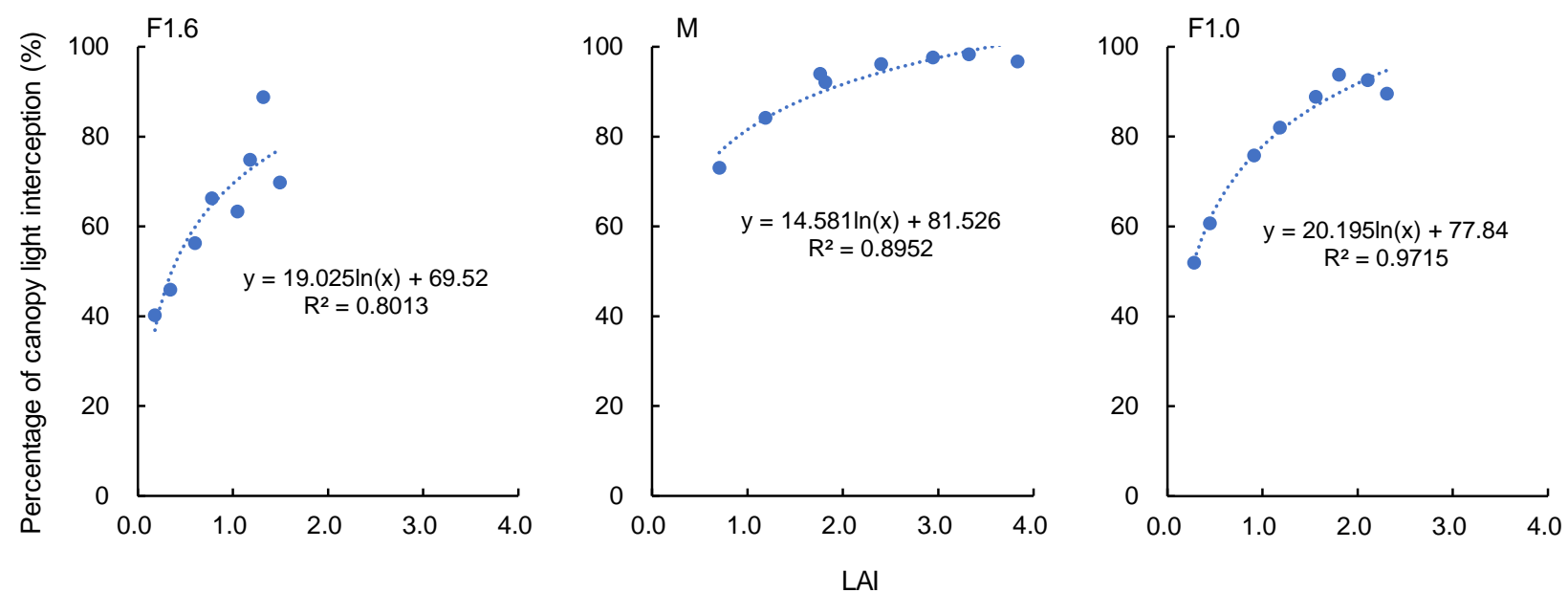

Figure 8. Relationship between the leaf area index (LAI) and percentage of canopy light interception from 7 to 55 days after transplanting. The figures were created using the data from Figures 4 and 6 . F1.6 and F1.0 indicate furrow distances of 1.6 and $1.0 \mathrm{~m}$, respectively; M indicates that the furrow distance was changed from 0.4 to $0.8 \mathrm{~m}$ during the cultivation using movable benches.

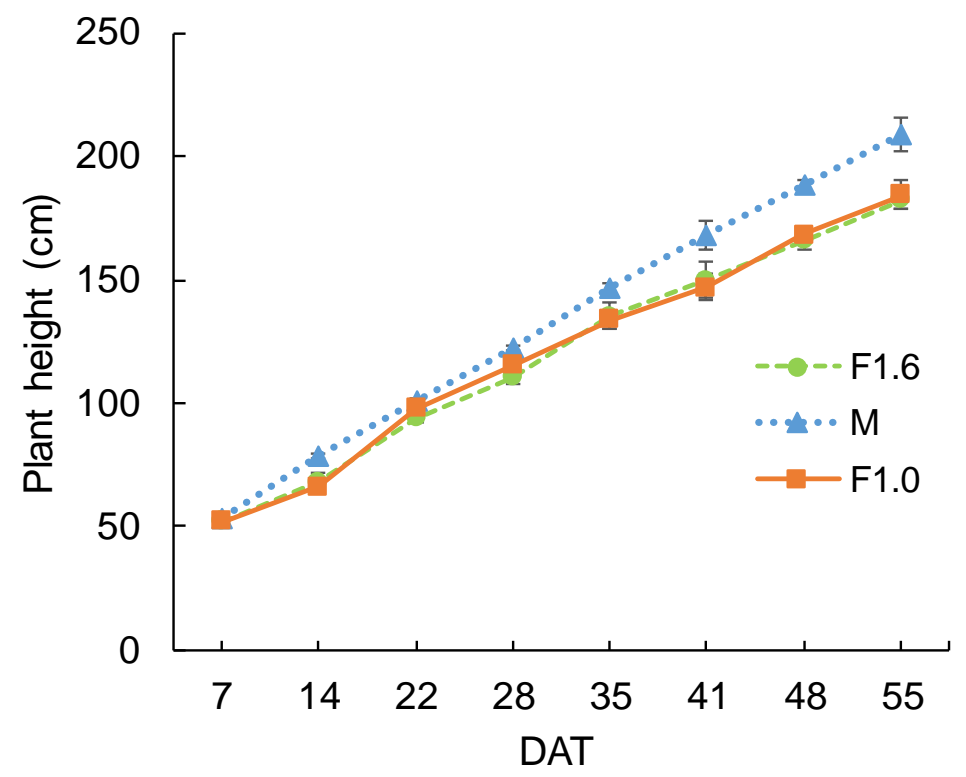

Figure 9. Changes in the plant height of tomatoes grown at different furrow distances $(n=3)$. F1.6 and F1.0 indicate furrow distances of 1.6 and $1.0 \mathrm{~m}$, respectively; $\mathrm{M}$ indicates that the furrow distance was changed from 0.4 to $0.8 \mathrm{~m}$ during cultivation using movable benches. DAT, days after transplanting. The error bars indicate standard error. Plant height was measured non-destructively.

Figure 10 shows the dry matter distribution calculated from growth measurements. At 30 and 62 DAT, the leaf dry matter distribution of plants in the M treatment was higher than those in the F1.6 and F1.0 treatments. At 62 DAT, the dry matter was more distributed to the fruit in the F1.6 treatment than in the M and F1.0 treatments because the fruit temperature of plants in the F1.6 treatment was higher than that of plants in the M treatment with a narrower furrow distance (Figure 11). Figure 11 shows the fruit temperatures of plants in the F1.6 and M treatments. The daytime fruit temperature of plants in the F1.6 treatment tended to be higher than that of plants in the $M$ treatment. The maximum difference in fruit temperature between plants in the F1.6 treatment and those in the M treatment was $4.6^{\circ} \mathrm{C}$. The increase in fruit temperature in the F1.6 treatment was slower than the increase in air temperature. However, around noon, the fruit temperature in the F1.6 treatment 
was higher than the air temperature in the greenhouse. Yoshioka et al. (1986) studied tomato fruit temperatures of 9,23 , and $38^{\circ} \mathrm{C}$, and they found that the translocation speed was faster at higher temperatures [20]. Fruits in the F1.6 treatment, with a wider furrow distance, received more solar radiation than those in the M and F1.0 treatments, resulting in higher fruit temperatures. Thus, changes in fruit temperature should be considered an important factor when cultivating plants using a movable bench system.

30 DAT

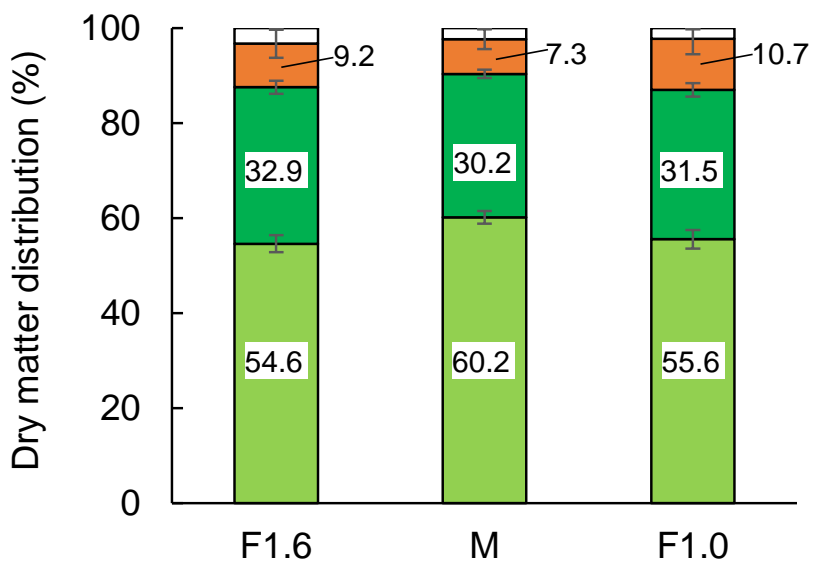

62 DAT

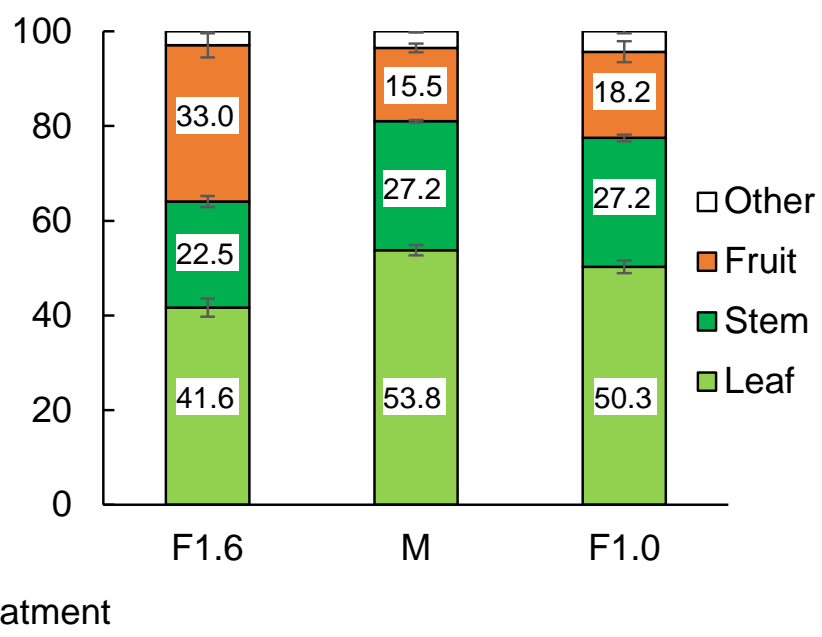

Figure 10. Effect of furrow distance on the dry matter distribution $(n=3)$. F1.6 and F1.0 indicate furrow distances of 1.6 and $1.0 \mathrm{~m}$, respectively; $\mathrm{M}$ indicates that the furrow distance was changed from 0.4 to $0.8 \mathrm{~m}$ during cultivation using movable benches. DAT, days after transplanting. The growth measurements were conducted on August 8 and September 9, 2018. The error bars indicate standard error.

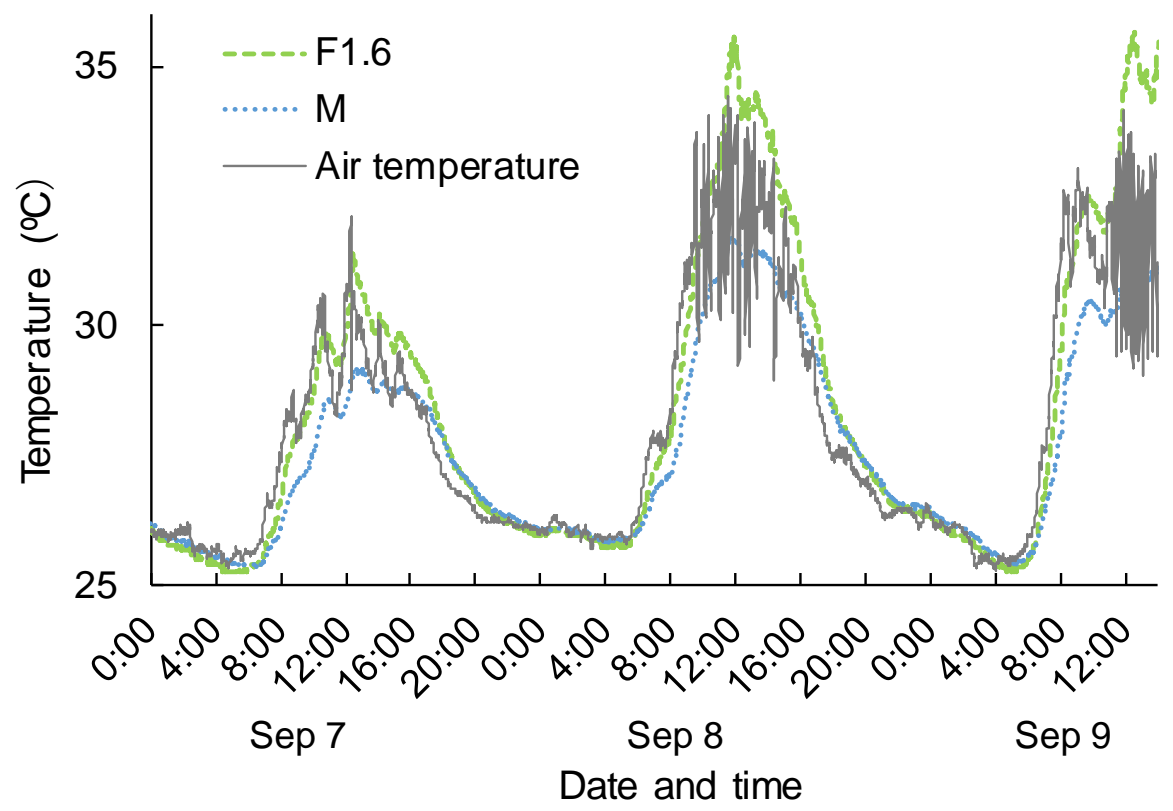

Figure 11. Changes in fruit temperatures and inside air temperature in the F1.6 and $M$ treatments $(n=3)$. Fruit temperature was measured on 60-62 days after transplanting. F1.6 indicates a furrow distance of $1.6 \mathrm{~m}$; $\mathrm{M}$ indicates that the furrow distance was changed from 0.4 to $0.8 \mathrm{~m}$ during cultivation using movable benches. 
Figure 12 shows the fruit yield per unit area. From highest to lowest, the yield per unit area was M > F1.0 > F1.6. The percentage of canopy light interception (Figure 5) had almost the same tendency as that of the yield per unit area. Therefore, the canopy of plants in the $\mathrm{M}$ treatment was able to efficiently intercept solar radiation inside the greenhouse. A linear relationship between light interception and yield was observed (Figure 13). Hence, if the light interception of canopies increases, it is possible to increase fruit yield per unit area. A movable bench can easily provide the canopy conditions to increase light interception, which can result in increased yields.

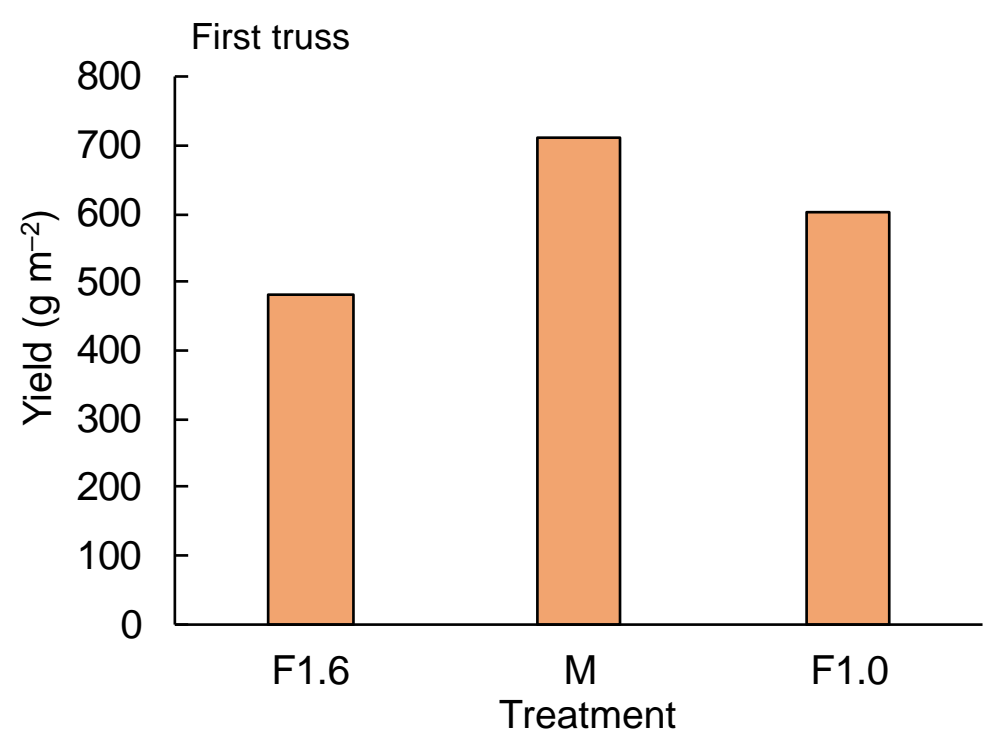

Figure 12. The yield per unit area of the first truss of tomatoes grown at different furrow distances. F1.6 and F1.0 indicate furrow distances of 1.6 and $1.0 \mathrm{~m}$, respectively; M indicates that the furrow distance was changed from 0.4 to $0.8 \mathrm{~m}$ during cultivation using movable benches. The yield was measured at 54 days after transplanting (DAT).

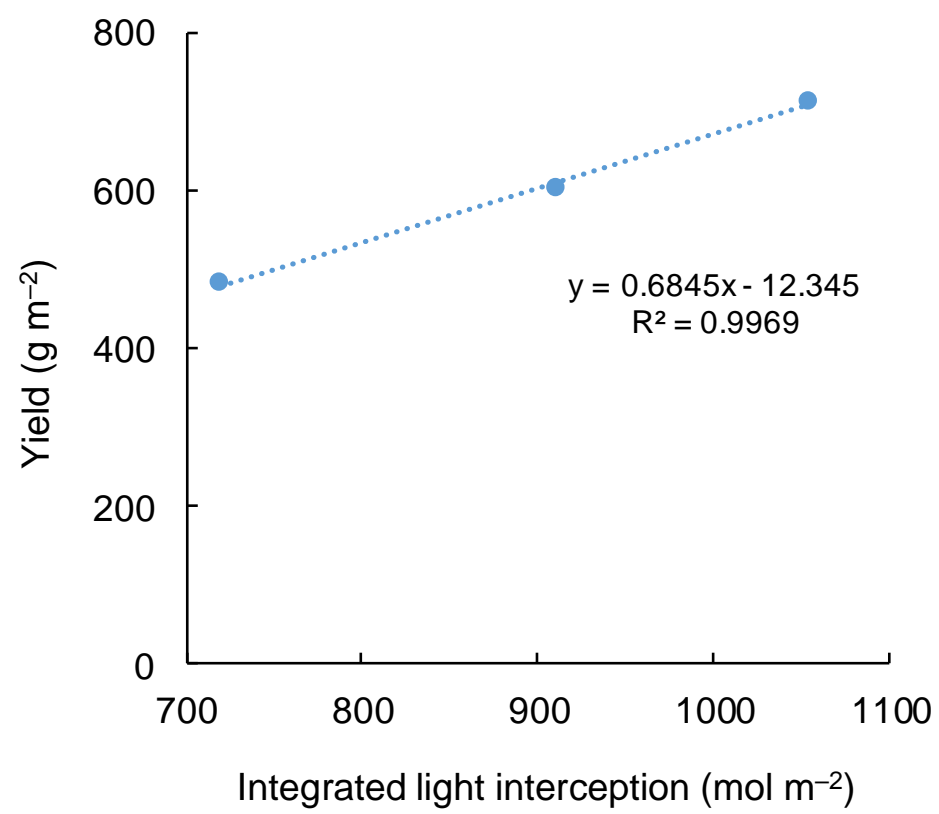

Figure 13. Relationship between the light interception of the canopy and yield. Yield survey of the first truss was conducted at 54 days after transplanting (DAT). Integrated light interception means integrated photosynthetic photon flux density from 6 to 54 DAT. 
In addition, Higashide et al. (2018) reported that when the LAI of tomatoes increased from 4 to 5 , the light interception of the canopy slightly increased [14]. Heuvelink et al. (2005) indicated that when the average LAI values of tomatoes were 3.3, 3.6, and 4.1, the yield of all treatments was $66 \mathrm{~kg} \mathrm{~m}^{-2}$ [25]. Accordingly, it is likely that LAI values that can saturate the yield may be in the range of 3-4. In the present study, the maximum LAI of plants in the M treatment was 3.8 (Figure 7), which was consistent with the results of previous studies. Therefore, if movable benches were installed to maintain the LAI at 3-4, the solar radiation inside the greenhouse could be efficiently intercepted by plants, thereby increasing the yield per unit area. However, light interception changes with the season, area, plant density, and greenhouse structure. Therefore, it is necessary to continue conducting cultivation tests under various conditions in the future.

\section{Conclusions}

The use of movable benches $(\mathrm{M})$ in greenhouse tomato cultivation resulted in an increase in the percentage of canopy light interception until the end of the cultivation period compared to those under cultivation at furrow distances of $1.6 \mathrm{~m}$ (F1.6) and $1.0 \mathrm{~m}$ (F1.0). Therefore, the solar radiation inside the greenhouse could be efficiently intercepted by plants when a movable bench was used during cultivation. In addition, the leaf area and height of plants in the $\mathrm{M}$ treatment were greater than those of plants in the other treatments. Furrow distance affected plant morphological traits, including plant leaf area and plant height. The yield per unit area for different treatments tended to increase in the order of F1.6 < F1.0 < M. Therefore, we concluded that it was possible to increase the plant yield per unit area using movable benches in tomato cultivation. Moreover, if movable benches were installed to maintain the LAI at 3-4, which saturates the yield, the solar radiation inside the greenhouse could be efficiently intercepted by plants, thereby increasing the yield per unit area.

Author Contributions: Methodology, investigation, analysis, validation, and writing —original draft preparation, Y.O.; methodology, investigation, and analysis, M.M.; methodology and validation, Y.I.; conceptualization, writing - review and editing, and funding acquisition, E.G. All authors have read and agreed to the published version of the manuscript.

Funding: This work was supported by the Strategic Project Research Promotion Program of the Ministry of Agriculture, Forestry, and Fisheries of Japan.

Conflicts of Interest: The authors declare no conflict of interest.

\section{References}

1. Rothan, C.; Diouf, I.; Causse, M. Trait discovery and editing in tomato. Plant J. 2019, 97, 73-90. [CrossRef]

2. Food and Agriculture Organization of the United Nations. FAOSTAT Statistical Database; FAO: Rome, Italy, 2021; Available online: https:/ / www.fao.org/faostat/en/\#data/QCL (accessed on 23 November 2021).

3. Shamshiri, R.R.; Jones, J.W.; Thorp, K.R.; Ahmad, D.; Man, H.C.; Taheri, S. Review of optimum temperature, humidity, and vapour pressure deficit for microclimate evaluation and control in greenhouse cultivation of tomato: A review. Int. Agrophys. 2018, 32, 287-302. [CrossRef]

4. van Os, E.A.; van Zuijdam, R.P.; Hendrix, A.T.M.; Koch, V.J.M. A moving fruit vegetable crop. Acta Hortic. 1993, 342, 69-76. [CrossRef]

5. Yoshida, H.; Yamamoto, S.; Hayashi, S.; Iwasaki, Y.; Urushiyama, Y. Development of a movable cultivation bench system for high-density of strawberries. J. Jpn. Soc. Agr. Mach. 2008, 70, 98-106. (In Japanese) [CrossRef]

6. Hayashi, S.; Yoshida, H.; Yamamoto, S.; Iwasaki, Y.; Urushiyama, Y. Design of a strawberry factory using a movable bench. Acta Hortic. 2008, 801, 653-659. [CrossRef]

7. Hayashi, S.; Saito, S.; Iwasaki, Y.; Yamamoto, S.; Nagoya, T.; Kano, K. Development of circulating-type movable bench system for strawberry cultivation. JARQ 2011, 45, 285-293. [CrossRef]

8. Jiang, C.; Johkan, M.; Hohjo, M.; Tsukagoshi, S.; Ebihara, M.; Nakaminami, A.; Maruo, T. Responses of leaf photosynthesis, plant growth and fruit production to periodic alteration of plant density in winter produced single-truss tomatoes. Hortic. J. 2017, 86, 511-518. [CrossRef]

9. Okano, K.; Nakano, Y.; Watanabe, S. Single-truss tomato system-A labor-saving management system for tomato production. JARQ 2001, 35, 177-184. [CrossRef] 
10. Papadopoulos, A.P.; Ormrod, D.P. Plant spacing effects on growth and development of the greenhouse tomato. Can. J. Plant Sci. 1991, 71, 297-304. [CrossRef]

11. Amundson, S.; Deyton, D.E.; Kopsell, D.A.; Hitch, W.; Moore, A.; Sams, C.E. Optimizing plant density and production systems to maximize yield of greenhouse-grown "Trust" tomatoes. HortTechnology 2012, 22, 44-48. [CrossRef]

12. Papadopoulos, A.P.; Ormrod, D.P. Plant spacing effects on yield of the greenhouse tomato. Can. J. Plant Sci. 1990, 70, 565-573. [CrossRef]

13. Papadopoulos, A.P.; Pararajasingham, S. The influence of plant spacing on light interception and use in greenhouse tomato (Lycopersicon esculentum Mill.): A review. Sci. Hortic. 1997, 69, 1-29. [CrossRef]

14. Higashide, T. Review of dry matter production and light interception by plants for yield improvement of greenhouse tomatoes in Japan. Hortic. Res. 2018, 17, 133-146. [CrossRef]

15. Blanco, F.F.; Folegatti, M.V. A new method for estimating the leaf area index of cucumber and tomato plants. Hortic. Bras. 2003, 21, 666-669. [CrossRef]

16. Poblete-Echeverría, C.; Fuentes, S.; Ortega-Farias, S.; Gonzalez-Talice, J.; Yuri, J.A. Digital cover photography for estimating Leaf area index (LAI) in apple trees using a variable light extinction coefficient. Sensors 2015, 15, 2860-2872. [CrossRef]

17. Monsi, M.; Saeki, T. Über den lichtfaktor in den pflanzengesellschaften und seine bedeutung für die stoffproduktion. Jpn. J. Bot. 1953, 14, 22-52.

18. Monsi, M.; Saeki, T.; Schortemeyer, M. On the factor light in plant communities and its importance for matter production. Ann. Bot. 2005, 95, 549-567. [CrossRef] [PubMed]

19. Flénet, F.; Kiniry, J.R.; Board, J.E.; Westgate, M.E.; Reicosky, D.C. Row spacing effects on light extinction coefficients of corn, sorghum, soybean, and sunflower. Agron. J. 1996, 88, 185-190. [CrossRef]

20. Yoshioka, H.; Takahashi, K.; Arai, K. Studies on the translocation and distribution of photosynthates in fruit vegetables. 9. Effects of temperature on translocation of 14C-photosynthates in tomato plants. Bull. Veg. Ornam. Crops Res. Sta. 1986, 14, 1-9. (In Japanese)

21. Kaneko, S.; Higashide, T.; Yasuba, K.; Ohmori, H.; Nakano, A. Effects of planting stage and density of tomato seedlings on growth and yield component in low-truss cultivation. Hortic. Res. 2015, 14, 163-170. [CrossRef]

22. Ota, T.; Iwasaki, Y.; Yamane, H.; Sugeno, W.; Kurosaki, H.; Ito, M.; Goto, C. Automatic spacing-controlled movable bench system for tomato production. Eng. Agric. Environ. Food. 2016, 9, 179-186. [CrossRef]

23. Papadopoulos, A.P.; Ormrod, D.P. Plant spacing effects on light interception by greenhouse tomatoes. Can. J. Plant Sci. 1988, 68, 1197-1208. [CrossRef]

24. Chitwood, D.H.; Kumar, R.; Ranjan, A.; Pelletier, J.M.; Townsley, B.T.; Ichihashi, Y.; Martinez, C.C.; Zumstein, K.; Harada, J.J.; Maloof, J.N.; et al. Light-induced indeterminacy alters shade-avoiding tomato leaf morphology. Plant Physiol. 2015, 169, 2030-2047. [CrossRef]

25. Heuvelink, E.; Bakker, M.J.; Elings, A.; Kaarsemaker, R.; Marcelis, L.F.M. Effect of leaf area on tomato yield. Acta Hortic. 2005, 691, 43-50. [CrossRef] 